\title{
Two Case of Stress Induced Cardiomyopathy after Injection of Epinephrine during Middle Ear Surgery
}

\author{
Hyung Gyun $\mathrm{Na}^{1}$, Si-Youn Song ${ }^{1}$, Yong-Dae Kim ${ }^{1,2}$, and Chang Hoon $\mathrm{Bae}^{1}$ \\ ${ }^{1}$ Department of Otorhinolaryngology-Head and Neck Surgery, College of Medicine, Yeungnam University, Daegu; and \\ ${ }^{2}$ Center for Respiratory Disease, Yeungnam University Medical Center, Daegu, Korea
}

\section{중이수술 중 에피네프린 주사 후 발생한 스트레스 유발성 심근증 2 예}

나형균 ${ }^{1} \cdot$ 송시연 ${ }^{1} \cdot$ 김용대 ${ }^{1,2} \cdot$ 배창훈 $^{1}$

영남대학교 의과대학 이비인후-두경부외과학교실, ${ }^{1}$ 영남대학교병원 권역 호흡기 전문질환센터 ${ }^{2}$

\author{
Received November 14, 2014 \\ Revised December 16, 2014 \\ Accepted December 19, 2014 \\ Address for correspondence \\ Chang Hoon Bae, MD, PhD \\ Department of Otorhinolaryngology- \\ Head and Neck Surgery, \\ College of Medicine, \\ Yeungnam University, \\ 170 Hyeonchung-ro, Nam-gu, \\ Daegu 705-717, Korea \\ Tel $+82-53-620-3784$ \\ Fax $+82-53-628-7884$ \\ E-mail baich@med.yu.ac.kr
}

Epinephrine is a common use to control bleeding for wide surgeon's range of vision during surgery. However, it may be occurred with some major complications such as reversible cardiomyopathy, pulmonary edema, and cardiac arrest. Stress-induced cardiomyopathy (SIC) is a reversible cardiomyopathy, which is related with sudden surge of catecholamine such as epinephrine, and increase of physical activity and emotional stress. It has been postulated that SIC is a relatively uncommon syndrome with difficult definition. But recently SIC is an increasingly recognized disease entity and is accepted as a unique form of reversible cardiomyopathy. However, SIC rarely is occurred when standard dose of epinephrine is used during a surgery under general anesthesia. Therefore, we presented two patients with SIC after subcutaneous injection of epinephrine during middle ear surgery.

Korean J Otorhinolaryngol-Head Neck Surg 2015;58(6):433-7

\section{서 론}

현재 이과학 영역의 수술에서 출혈을 줄이기 위해 혈관 수 축작용이 있는 epinephrine을 수술부위에 국소주사 또는 점 막 도포의 형태로 널리 이용하고 있다. 허용 범위 용량 내의 epinephrine 사용은 그 자체가 심혈관계에 영향을 미쳐 심계항 진, 빈맥, 부정맥과 같은 부작용을 일으킬 수 있고, 과량 사용되거 나 혈관에 직접 주입될 경우 전신 흡수에 의한 심독성이 발 현되어 심근증, 폐부종, 심정지 등의 심각한 합병증이 일어날 수 있다. ${ }^{1)}$

Epinephrine과 같은 catecholamine의 증가에 의한 심근 증은 1969년 지주막하출혈 환자에게서 처음 보고되었고, ${ }^{2)}$ 크롬친화세포종 환자의 내인성 catecholamine 증가에 의한 심근증과 epinephrine을 국소주사한 후 발생한 심근증에 대 해 다수의 증례를 찾아볼 수 있으나, 이과학 영역의 수술에서
허용범위 용량 내의 epinephrine 국소주사 후 발생한 심근증 은 극히 드물다. ${ }^{3-5)}$

심근증 중 하나인 스트레스 유발성 심근증(stress induced cardiomyopathy, $\mathrm{SCI}$ )은 개별적인 관상동맥의 혈액 공급부위 와는 무관하게 수축기에 심기저부의 심근운동만 살아있고 심 첨부가 풍선처럼 부풀어 오르는 양상(apical ballooning)을 보 이는 심장질환으로, 갑작스런 감정적인 스트레스, 물리적 활동 의 증가, catecholamine의 갑작스런 증가 등이 원인으로 추정되 고 있으며, 급성 심근경색증의 진단기준에 부합하나, 관상 동 맥 조영술상 의미 있는 협착이나 폐쇄소견은 보이지 않는 질환 을 지칭한다. ${ }^{6}$

이에 저자들은 수술 전 시행한 심전도 및 혈액검사에서 특이 소견을 보이지 않았던 환자에서 중이 수술 중 허용범위 내 용 량의 epinephrine을 피하주사 후 발생한 심근증 2예를 경험 하였기에 문헌고찰과 함께 보고하는 바이다. 


\section{증 례}

\section{증 례 1}

28세 남자 환자가 수년간 지속되는 우측 이루와 청력감퇴를 주소로 내원하였다. 과거력상 다른 기저 질환은 없었다. 신체 검사에서 우측 고막에 중심부 소천공이 관찰되었고, 좌측 고 막은 특이 소견이 없었다. 순음 청력검사(3분법)상 양측 모두 정상소견을 보였고 측두골 단층촬영에서 특이소견이 관찰되 지 않았다. 환자는 수술 전 시행한 혈액검사, 소변검사, 단순 흥부촬영상에서 특이소견이 관찰되지 않았고, 심전도 검사 에서 정상 동율동과 정상 심박동 소견을 보였다(Fig. 1A).

우측 고막고실 성형술을 계획하고 수술을 시행하였다. 환자는 마취 유도 직전까지 혈압은 130(수축기)/90(이완기) $\mathrm{mm} \mathrm{Hg}$, 심박수는 60 회, 호흡수는 20 회, 체온은 $36.4^{\circ} \mathrm{C}$ 로 안정된 소견을 보였다. 마취 유도를 위해 fresofol ${ }^{\circledR}$ (propofol) $100 \mathrm{mg}$, esmeron ${ }^{\circledR}$ (rocuronium) $50 \mathrm{mg}$ 과 ultiva ${ }^{\circledR}$ (remifentanyl) $1 \mathrm{mg}$ 을 사용 하여 sevofran ${ }^{\circledR}$ (sevoflurain)으로 흡입 마취를 시작하였고, 수술 시작 전까지 활력징후에 특이소견은 보이지 않았으며 수 술 중 마취 심도감시장치(bispectral index ${ }^{\circledR}$ 를 이용하여 전신
마취 심도를 충분히 유지하였다.

고막고실 성형술을 시행하기 위해 우측 귀 후방의 피부에 1:200000 epinephrine-lidocaine 희석액 $4 \mathrm{~mL}$ 를 피하주사하고, 약 30초 정도 압박한 후 피부절개를 시행하였다. 우측 귀 후 방의 피부 절개 도중 200/130 mm Hg로 갑작스런 혈압 상승 과 빈맥 소견을 보여 수술을 중지한 후 활력 증상 조절을 위한 조치로 베타 차단제인 brevibloc ${ }^{\circledR}$ (esmolol HCl) $20 \mathrm{mg}$ 을 투 여하였으나, 환자의 혈압은 220/180 mm Hg까지 오르는 양상을 보였다. 이에 흡입 마취의 강도를 증가시키면서 brevibloc ${ }^{\circledR} 20$ $\mathrm{mg}$ 을 순차적으로 2회 투여한 후 환자의 혈압은 $120 / 65 \mathrm{~mm} \mathrm{Hg}$ 로, 심박수는 80회로 조절되었으나, 마지막 brevibloc ${ }^{\circledR}$ 투여 후 10 분이 지나면서 환자의 혈압은 $80 / 45 \mathrm{~mm} \mathrm{Hg}$ 로 하강하여, 알파 작용제인 phenylephrine ${ }^{\circledR}($ phenylephrine $\mathrm{HCl}) 50 \mu \mathrm{g}$ 을 3회 주 사하여 환자의 혈압은 $110 / 55 \mathrm{~mm} \mathrm{Hg}$ 로, 심박수는 85회로 안 정화되었다. 하지만 심전도 검사 소견에서 II, III, aVF, V4-6 전극 에서 ST 분절의 하강소견이 관찰되어 수술을 중단하고 환자 를 회복실로 이동하였다(Fig. 1B). 수술 중단 후 의식을 회복 한 환자는 경미한 두근거림과 흥부 불편감을 호소하였고, 회 복실에서 시행한 심장 초음파 검사상 중벽의 전반적 운동감
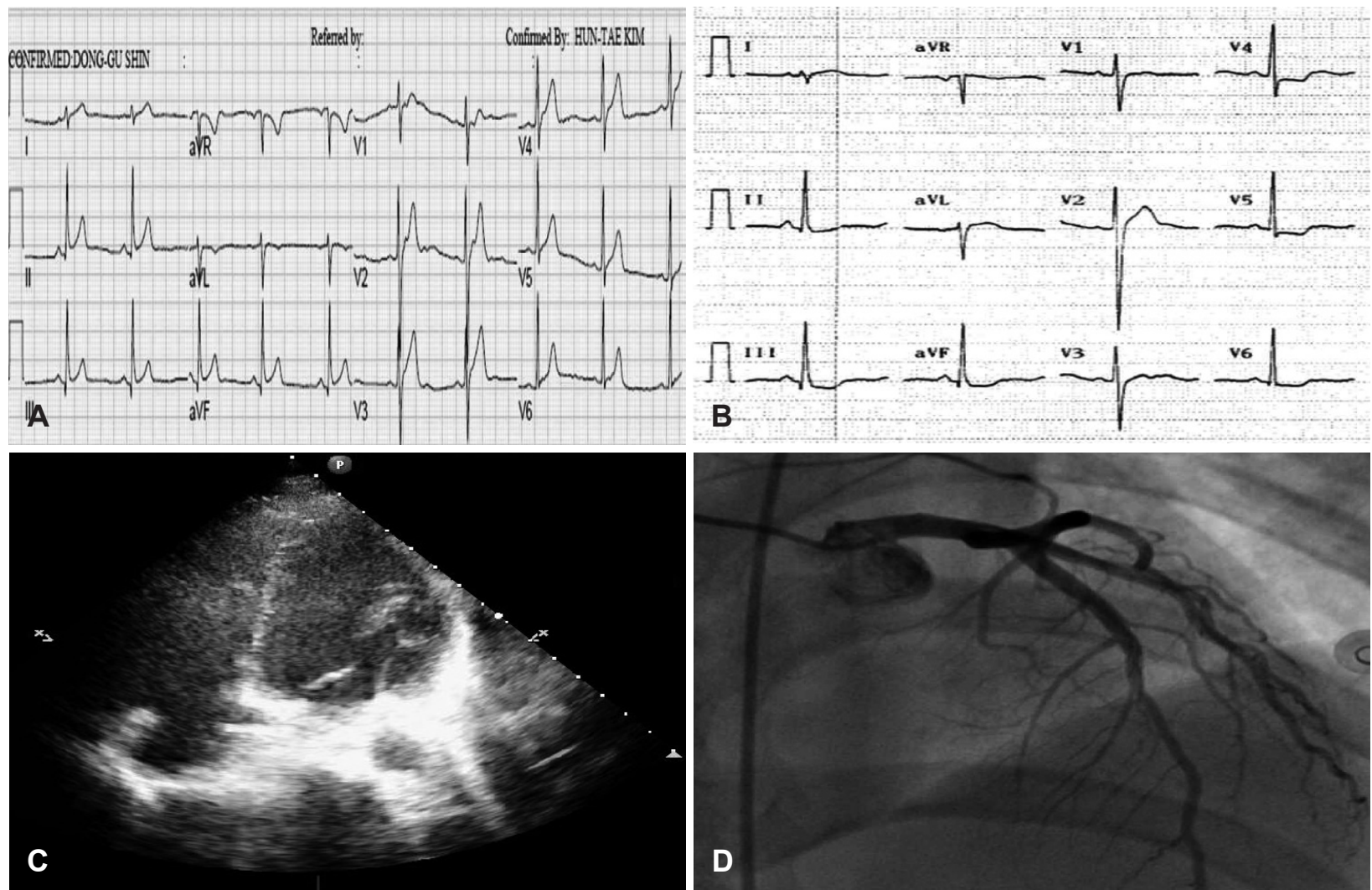

Fig. 1. Electrocardiogram, echocardiogram, and coronary angiogram of case 1. The preoperative electrocardiogram shows normal sinus rhythm (A). The postoperative electrocardiogram at 1 hour after the operation shows sinus trachycardia and ST segment change at lead of II, III, aVF, V4, V5, and V6 (B). Apical 4-chamber view of transthoracic echocardiogram at bed side after operation shows global hypokinesis at mid-ventricular level of left ventricle and mild regurgitation of the mitral valve (C). Coronary angiogram at 1 day after the operation shows absence of significant luminal obstruction in the coronary arteries (D). 
소 소견이 보였다(Fig. 1C). 수술 중단 직후 측정한 심근효소 검 사상 creatine kinase-myocardial band(CK-MB)와 N-terminal of the prohormone brain natriuretic peptide(NT-proBNP)는 정상소견이었으나, troponin $\mathrm{I}$ 는 $2.3 \mathrm{ng} / \mathrm{mL}$ 로 증가하였고 수 술 중단 6시간째 $8.08 \mathrm{ng} / \mathrm{mL}$ 로 더욱 증가된 소견을 보였다. 수술 중단 1일째 심장 관상동맥 조영술을 시행하였으나 특이 소견은 관찰되지 않았다(Fig. 1D). 수술 중단 3일째 troponin $\mathrm{I}$ 는 $0.46 \mathrm{ng} / \mathrm{mL}$ 로 급격히 감소하였고, 활력 징후에서도 특이 소견이 보이지 않아서, 환자는 수술 중단 6 일째 퇴원하였으며, 현재 정기적인 외래 경과 관찰 중이다.

\section{증 례 2}

51세 남자 환자가 좌측 청력감퇴와 이명을 주소로 내원하였 다. 과거력상 다른 내과적 기저질환은 없었다. 신체 검사상 좌 측 고막은 상고실의 심한 함몰 소견을 보였고, 우측 고막은 특 이 소견이 없었다. 순음 청력검사(3분법)상 좌측은 중등고도 전음성 난청이었고, 우측은 정상 청력이었다. 측두골 전산화단 층촬영에서는 좌측 중이와 유양동 내에 염증 소견이 관찰되었 다. 환자는 수술 전 시행한 혈액검사, 소변검사, 단순흥부촬영 상에서 특이소견이 관찰되지 않았고, 심전도 검사에서 정상 동 율동과 정상 심박동 소견을 보였다(Fig. 2A).

좌측 고막고실 성형술과 유양동 삭개술을 계획하고 수술을 시행하였다. 환자는 마취 유도 직전까지 혈압은 $130 / 90 \mathrm{~mm} \mathrm{Hg}$, 심박수는 64 회, 호흡수는 20 회, 체온은 $36.5^{\circ} \mathrm{C}$ 로 안정된 소견을 보였다. 마취 유도를 위해 fresofol ${ }^{\circledR} 100 \mathrm{mg}$, esmeron ${ }^{\circledR} 50 \mathrm{mg}$ 과 ultiva ${ }^{\circledR} 1 \mathrm{mg}$ 을 사용하여 sevofran ${ }^{\circledR}$ 으로 흡입 마취를 시작 하였고, 수술 시작 전까지 활력징후에 특이소견은 보이지 않 았으며 수술 중 마취 심도감시장치(bispectral index ${ }^{\circledR}$ 를 이용 하여 전신마취 심도를 충분히 유지하였다.

고막 고실 성형술과 유양동 삭개술을 시행하기 위해 좌측 귀 후방의 피부에 1:200000 epinephrine-lidocaine $4 \mathrm{~mL}$ 를 국 소주사하고, 약 30초 정도 압박한 후 피부절개를 시행하였다.
좌측 귀 후방의 피부 절개 도중 환자의 혈압은 260/130 mm Hg 로 갑자기 증가되고, 심박수도 130회로 빈맥이 관찰되어서 수 술을 중지한 후 활력 증상 조절을 위한 조치로 brevibloc ${ }^{\circledR} 10 \mathrm{mg}$ 을 투여하였다. 하지만 환자의 혈압이 250/130 mm Hg로 조 절되지 않아, 흡입 마취의 강도를 증가시키면서 brevibloc ${ }^{\circledR}$ 을 순차적으로 $20 \mathrm{mg}$ 과 $10 \mathrm{mg}$ 을 투여하여 환자의 혈압은 190/ $100 \mathrm{~mm} \mathrm{Hg}$ 로, 심박수는 110회로 조절되었으나, 마지막 brevibloc $^{\circledR}$ 투여 후 10 분이 지나면서 환자의 혈압은 90/60 mm Hg 로 하강하여, phenylephrine ${ }^{\circledR} 50 \mu \mathrm{g}$ 을 3회 주사하여 환자의 혈압은 120/80 mm Hg로, 심박수는 90회로 안정화되었다. 수술을 재개하였고 종료시까지 최대 혈압은 $130 / 90 \mathrm{~mm} \mathrm{Hg}$, 최저 혈압은 90/60 mm Hg였고, 심박수는 90회 이하, 혈액 내 산소포화도는 $\left(\mathrm{pO}_{2}\right) 95 \%$ 이상으로 유지되었다.

수술 종료 후 환자는 경미한 두근거림과 흉부 불편감을 호 소하였고, 수술 회복실에서 시행한 심전도 검사상 동빈맥, 심 근 전외벽 허혈 소견을 보이는 $\mathrm{T}$ 파의 이상과 중등도의 우축 편위가 관찰되었다(Fig. 2B). 심장 초음파 검사상 좌심실 구혈 률은 $40 \%$ 로 감소하였고, 좌심실의 심첨부가 풍선처럼 부풀어 오르는 소견(apical ballooning appearance)이 관찰되어 스트 레스 유발성 심근증으로 진단하였다(Fig. 2C). 수술 후 측정한 심근효소 검사상 $\mathrm{CK}-\mathrm{MB}$ 와 NT-proBNP는 정상소견이었으나, troponin I는 $6.43 \mathrm{ng} / \mathrm{mL}$ 까지 증가하였다. 수술 후 1일째 tropo$\operatorname{nin} I$ 가 $3.7 \mathrm{mg} / \mathrm{mL}$ 로 급격하게 감소하였고, 환자의 경미한 흥 부증상마저 소실되어 심장 관상동맥 조영술은 시행하지 않았 다. 수술 후 8일째 troponin I이 $0.02 \mathrm{mg} / \mathrm{mL}$ 로 정상화되어 환 자는 퇴원하였고, 현재 외래를 통한 정기적 경과 관찰 중이다.

\section{고 찰}

$\mathrm{SIC}$ 는 갑작스런 정신적 혹은 육체적 스트레스, 물리적 활 동의 증가 및 epinephrine의 갑작스런 증가 등의 요인으로 인 하여 심장에 가역적인 심근병증이 생기는 질환이다. ${ }^{4)} \mathrm{SIC}$ 는
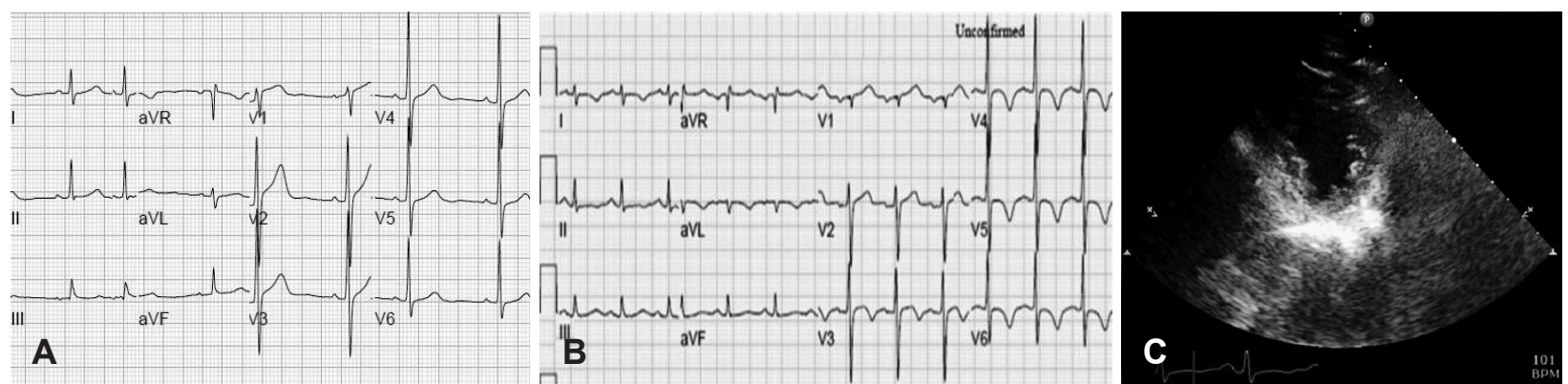

Fig. 2. Electrocardiography and echocardiography of case 2. The preoperative electrocardiography shows normal sinus rhythm (A). The postoperative electrocardiography at 1 hour after the operation shows sinus trachycardia, T wave inversion and ST segment change at $\mathrm{V} 3, \mathrm{~V} 4, \mathrm{~V} 5$, and $\mathrm{V} 6$ (B). Apical 2-chamber view of transthoracic echocardiography at bed side after the operation shows the left ventricle wall motion irregularity, apical malfunction and increment of the left ventricle apical volume (C). 
1990년대 초반 일본에서 처음 발견되었으며, ${ }^{6)}$ 심장조영술시 나타나는 심장의 모양이 일본에서 문어를 잡을 때 쓰이는 특 이한 모양의 항아리인 Takotsubo와 유사하여 이를 Takotsubo cardiomyopathy라고 명명하기도 한다., ${ }^{5,6)}$ 현재까지 SIC는 많 은 증례와 임상적 특징들이 보고되고 있으나, 아직까지 SIC의 발생기전이나 병리생태가 명확하게 밝혀지지 않아 acute coronary syndrome(ACS)과 본질적으로 다른 질환인가에 대해서는 논란의 여지가 있다. ${ }^{78)}$ 지금까지 알려진 SIC의 발생기전과 병 리생태는 catecholamine 분해시 형성되는 산소 유리기에 의한 세포막, 근세포의 괴사, 혈소판 응고 촉진 등에 의해 야기되는 혈관폐쇄, 칼슘의 세포 내 유입에 따른 근세포 손상이나 과수 축 등에 의한 것으로 보고되고 있다. ${ }^{9)}$

$\mathrm{SIC}$ 를 진단하기 위해서는 첫째로 환자가 이전에 특이적 심장 질환이 없으면서 새로운 심전도의 ST 분절 상승 혹은 T파 역 전 혹은 심근효소 troponin I의 중증도 이상의 상승을 나타내 야 한다. 둘째로 심장 초음파 검사에서 일시적인 좌심실의 중 간분절의 저운동성, 무운동성 혹은 이상 운동에서부터 국소 적인 심근 수축력 저하소견까지 다양한 초음파 소견을 확인 해야 하며, 마지막으로 $\mathrm{ASC}$ 와 감별진단을 위해 심장 관상동 맥 조영술상 폐쇄성 관상동맥 질환의 증거가 없어야 한다. ${ }^{10)}$ 국내에서 보고된 epinephrine에 의한 스트레스성 심근병증은 이비인후과뿐만 아니라 안과, 성형외과 등의 다른 두경부 수 술에서 상대적으로 많이 보고되고 있으며 이는 두경부의 풍부 한 혈액분포가 원인이 될 수 있을 것이라 추정된다. ${ }^{4,11,12)}$ 증례 1 의 경우에 전신마취 수술로 인한 감정적 스트레스에 의한 catecholamine의 증가에 따른 $\mathrm{SIC}$ 의 발생 가능성을 고려해 볼 수 있으나, 수술 중 epinephrine을 피하주사 후 혈압이 급 격히 상승하면서 심전도의 이상소견과 심장 초음파 검사에서 좌심실의 중간분절의 저운동성을 보였으며 심장 관상동맥 조 영술에서 정상 소견을 나타내어 SIC로 진단할 수 있었다. 증 례 2의 경우에 환자의 경미한 두근거림과 흥부 불편감과 같은 흥부 증상이 빠르게 소실되고, 활력 징후도 정상 소견을 보여 심혈관 조영술은 시행하지 않아, 폐쇄성 관상동맥 질환의 소견 을 확인할 수 없었다. 하지만 환자가 기존 심장 질환이 없었고, 수술 후 시행한 심전도 검사, 혈중 심근효소 troponin I의 수 치와 심장 초음파 검사의 소견이 전형적인 SIC 양상을 나타내 어 epinephrine에 의한 SIC로 진단할 수 있었다.

$\mathrm{SIC}$ 의 치료는 현재 $\mathrm{ACS}$ 의 급성기 치료와 크게 다르지 않 으며, 특히 epinephrine에 의한 SIC는 대부분 대증적인 치료와 적절한 혈역학적 지지 요법에 의해 치료되는 가역적인 양상을 보인다. 그러나, 빈맥과 고혈압이 지속적으로 동반되거나 악화 되면 혈관 확장제로 혈압을 낮추어야 한다. 항고혈압제로는 알 파 차단제를 사용하고, 베타 차단제나 칼슘 채널 차단제는 오
히려 심부전을 야기할 수 있으므로 사용에 유의해야 한다. ${ }^{13)} \mathrm{SIC}$ 는 예후가 매우 좋은 질환으로 알려져 있고, 사망률은 0 8\% 정 도로 보고되었다. ${ }^{14)} \mathrm{SIC}$ 의 가장 흔한 합병증은 좌심실부전이며, 그 증상은 대부분 2 3일 내에 없어지고 좌심실 기능은 1 4주 이내에 회복된다.

본 증례를 통해 이비인후과 수술에서 지혈을 위해 흔히 사용 되는 epinephrine을 허용 범위 이내의 피하주사에 의해서도 $\mathrm{SIC}$ 가 발생될 수 있음을 알 수 있었다. 또한 epinephrine에 의 한 $\mathrm{SIC}$ 를 예방하기 위하여 수술 전에는 항상 환자를 안정되도 록 유지시키고, 수술 중 epinephrine을 국소주사시에 직접 혈 관 내로 잘못 유입되지 않는지 혈액 음성 흡인 확인을 소홀히 해서는 안되며, 먼저 epinephrine을 소량 국소주사한 후 환자 의 반응을 살펴보고 추가적인 epinephrine의 국소주사와 수술 을 진행하는 등의 각별한 주의가 필요하다고 생각된다.

\section{REFERENCES}

1) Kassim TA, Clarke DD, Mai VQ, Clyde PW, Mohamed Shakir KM. Catecholamine-induced cardiomyopathy. Endocr Pract 2008;14 (9):1137-49.

2) Hammermeister KE, Reichenbach DD. QRS changes, pulmonary edema, and myocardial necrosis associated with subarachnoid hemorrhage. Am Heart J 1969;78(1):94-100.

3) Sardesai SH, Mourant AJ, Sivathandon Y, Farrow R, Gibbons DO. Phaeochromocytoma and catecholamine induced cardiomyopathy presenting as heart failure. Br Heart J 1990;63(4):234-7.

4) Cho CK, Jung SM, Kim JY, Kwon HU, Kang PS. Stress induced cardiomyopathy after local epinephrine use: a case report. Korean J Anesthesiol 2008;54(5):581-4.

5) Sato Y, Tanaka M, Nishikawa T. Reversible catecholamine-induced cardiomyopathy by subcutaneous injections of epinephrine solution in an anesthetized patient. Anesthesiology 2000;92(2):615-9.

6) Sato H, Tateishi H, Uchida T, Dote K, Ishihara M. Tako-tsubo-like left ventricular dysfunction due to multivessel coronary spasm. In: Kodama K, Haze K, Hori M, editors. Clinical Aspect of Myocardial Injury: from ischemia to heart failure. Tokyo: Kagakuhyoronsya; 1990. p.56-64.

7) Tsuchihashi K, Ueshima K, Uchida T, Oh-mura N, Kimura K, Owa M, et al. Transient left ventricular apical ballooning without coronary artery stenosis: a novel heart syndrome mimicking acute myocardial infarction. Angina Pectoris-Myocardial Infarction Investigations in Japan. J Am Coll Cardiol 2001;38(1):11-8.

8) Kurisu S, Sato H, Kawagoe T, Ishihara M, Shimatani Y, Nishioka K, et al. Tako-tsubo-like left ventricular dysfunction with ST-segment elevation: a novel cardiac syndrome mimicking acute myocardial infarction. Am Heart J 2002;143(3):448-55.

9) Jiang JP, Downing SE. Catecholamine cardiomyopathy: review and analysis of pathogenetic mechanisms. Yale J Biol Med 1990;63 (6):581-91.

10) Lau TK, Navarijo J, Stainback R. Pseudo-false-positive exercise treadmill testing caused by systolic anterior motion of the anterior mitral valve leaflet. Tex Heart Inst J 2001;28(4):308-11.

11) Kim CJ, Kim JM, Jang YH, Shin YS. Cardiomyopathy after local infiltration or application of epinephrine for plastic surgery under general anesthesia: two cases report. Korean J Anesthesiol 2009;56 (6):725-8

12) Kim JY, Choi SR, Lee SC, Chung CJ. Acute pulmonary edema due to local epinephrine injection during tonsillectomy: a case report. Korean 
Stress Induced Cardiomyopathy during Middle Ear Surgery I Na HG, et al.

J Anesthesiol 2004;47(6):890-3.

13) Kalyanaraman M, Carpenter RL, McGlew MJ, Guertin SR. Cardiopulmonary compromise after use of topical and submucosal alpha-agonists: possible added complication by the use of beta- blocker therapy. Otolaryngol Head Neck Surg 1997;117(1):56-61.

14) Prasad A, Lerman A, Rihal CS. Apical ballooning syndrome (TakoTsubo or stress cardiomyopathy): a mimic of acute myocardial infarction. Am Heart J 2008;155(3):408-17. 